\title{
EFFECT OF POLYPHENOLIC COMPOUNDS ISOLATED FROM NANDINA DOMESTICA. THUNB. LEAVES GROWING IN EGYPT AGAINST INDUCED ECZEMA IN MICE. \\ kamilia Fouly Taha ${ }^{1}$, Eman Shawky Anwar ${ }^{2}$,Marwa Samy Abu Bakr ${ }^{3}$, Marwa Khalil Raafat $^{3 *}$. \\ ${ }^{1}$ Department of Pharamacognosy in Applied Research Center of Medicinal Plants, Giza, Egypt \\ ${ }^{2}$ Department of pharmacognosy, Faculty of Pharmacy, Alexandria University, Alexandria, Egypt \\ ${ }^{3}$ Department of pharmacognosy, Faculty of Pharmacy (girls), Al-Azhar University Cairo, Egypt.
}

\section{*Corresponding author: meraph37@gmail.com}

\begin{abstract}
Herbal therapy is considered as the new world attitude; this might be attributed to the safety offered by the natural medicinal products with respect to the traditional synthetic therapeutic agents. Berberidaceae, family comprising 14 genera and 701 species of perennial herbs and shrubs. Phytochemical investigation of Ethyl acetate fraction of dried leaves of Nandina domestica led to the isolation of four compounds (1 -4). The isolated compounds were identified by their NMR, MS spectral data analysis as caffeic acid (1), chlrogenic acid (2), quercetin (3) and rutin (4). This is the first report of isolation of chemical entities from leaves of this plant. Ethyl acetate fraction of Nandina domestica, exhibited antieczyma activity against induced eczema in mice
\end{abstract}

Keywords: Nandina domestica, antieczyma, caffiac acid, chlrogenic acid, quercetin rutin.

\section{Introduction}

One of important members of interest include Nandina domestica Thunb. The only species in the genus. Nandina domestica Thunb. It is a monotypic genus(Bi.et $a l, 2015)$. Phytochemical analysis of various species of genus revealed the presence of alkaloids, tannins, phenolic compounds, sterols and triterpenes. (Mokhber: ;2013). Eczema (Dermatitis) is mostly acute, less frequently chronic, recurrent, non-contagious inflammatory condition of the skin; it represents an allergic response to a variety of agents that react on the skin from either the outside or the inside. It is characterized by redness, itching, blistering, oozing, weeping; scaling, thickening of skin. (Skripkin Y.K. et al., Abdallah M.A.-R., et al., (1994), Phelps R.G., et al., (2003) \&Mohammed A. Mahdy, (2004). Acute eczema is presented as ill-defined erythematous edematous patches that may show papules, vesicles, oozing areas, or crusts. Due to the diversity of causes of eczema and types of reaction, treatment should be planned to suit each case individually. It is important to try to find the possible cause and to tell the patient how to avoid it. The following are the measures that may be applied in a case of eczema, Systemic therapy, Topical therapy (Feingold S., et al., (1998)., Cabral P.S., et al., (2003). available online at http://www.hkmj.org.hk/skin/stdframe.htm), Psoralens plus ultraviolet light (PUVA), Immunosuppressive (Dattner A.M.; (2003). Hehmann M., et al., (2004) , Carvalho J.C.T., et al., (1999).Khandpur S., et al., (2004), Donfack J. et al., (2011) Lv YJ, et al.,2008\& Saxena N., et al., (1988).\& Phototherapy (WHO 
Monographs On Selected Medicinal Plants (1999),Congora L., et al.,(2002)\&Kimata M., et al., (2000). Mills' S. et al., (2002) \& Graf J. (2002).

\section{Material and methods:}

\section{phytochemical study:}

Leaves and of Nandina domestica Thunb. were collected from El-Orman botanical garden, Cairo, Egypt in 2015. The dry ground leaves of Nandina domestica. (1 $\mathrm{Kg}$ ) were extracted with $70 \%$ alcohol several times, isolation and identification of the active constituents The English Text of The Egyptian Pharmacopoeia (1984) \& Stahl E. (1969).

The total extract was concentrated under reduced pressure and subjected to successive fractionation with methylene chloride, ethyl acetate \& butanol. ethyl acetate fraction was applied on silica gel column and eluted with $\mathrm{CH}_{2} \mathrm{Cl}_{2}: \mathrm{MeOH}$ from 95:5 to 15:85 to obtain 10 collective fractions. Fraction 5 was subjected to successive column chromatography on Sephadex LH-20 using methanol to offered four compounds 1, 2, 3, \&4 which subjected to ESI -mass and ${ }^{1} \mathrm{H}$ - and ${ }^{13} \mathrm{C}$-NMR measurements (Ain shams University), spectrometer operating at $400 \mathrm{MHz}$ (for ${ }^{1} \mathrm{H}$ ) and $100 \mathrm{MHz}$ (for ${ }^{13} \mathrm{C}$ ).

\section{biological studies Treatment of induced eczema in mice:}

A) Preparation of the extracts and ointments: ethyl acetate fraction was used in preparation of $2 \%$, ointments in Vaseline base.

B) Animals: Male albino mice weighing (25-30 g) were used; the animals were kept in groups of 8 animals in each polyethylene cage at room temperature. They were fed on standard chow, and allowed free access to drinking water. They were acclimatized at least for one week prior to use.

C) Preparation of dinitrochlorobenzene (DNCB): The first sensitizing dose was $2 \% \mathrm{w} / \mathrm{v}$ $\mathrm{DNCB}$ in acetone and the second one was $0.2 \% \mathrm{w} / \mathrm{v}$ for further application if eczema still not formed.

D) Induction of eczema: Each mice group (8) was sensitized by local application of $2 \%$ DNCB. In about $90 \%$ of the animal the eczema was formed after 4 days. To the rest of animals $0.2 \% \mathrm{w} / \mathrm{v}$ of DNCB solution is applied locally and the eczema was formed after 2 days.

E) Treatment of the induced eczema in mice: Groups of mice (8 each) were treated once daily with ointments of different extracts $(2 \% \mathrm{w} / \mathrm{w}$ ethyl acetate fraction in Vaseline) and compared with positive control (mometasone furoate ointment Elocon ${ }^{\circledR}$ ointment).

F) The data expressed as percentage of number of healed animals in test period in respect to total number of treated animals

\section{Results and discussion}

Phytochemical investigation of Ethyl acetate fraction of dried leave of Nandina domestica led to the isolation of four compounds (1 -4). The isolated compounds were identified by their NMR, MS spectral data analysis as caffiac acid (1), chlrogenic acid (2), quercetin (3) \& rutin (4). 


\section{Compound 1}

It was isolated as creamy amorphous powder. ESI-MS of the compound showed $[\mathrm{M}-\mathrm{H}]^{+}$peak at $\mathrm{m} / \mathrm{z}$ 179.1, which is compatible with the molecular formula $\mathrm{C}_{9} \mathrm{H}_{8} \mathrm{O}_{4}$. The ${ }^{1} \mathrm{H}$ NMR spectrum of the compound exhibited characteristic signals for $\delta 7.57(1 \mathrm{H}$, $\mathrm{d}, J=16 \mathrm{~Hz}, \mathrm{H}-7), 7.06(1 \mathrm{H}, \mathrm{d}, J=2.0 \mathrm{~Hz}, \mathrm{H}-2), 6.96(1 \mathrm{H}, \mathrm{dd}, J=8.0,2.0 \mathrm{~Hz}, \mathrm{H}-6)$, $6.94(1 \mathrm{H}, \mathrm{d}, J=8.0 \mathrm{~Hz}, \mathrm{H}-5), 6.26(1 \mathrm{H}, \mathrm{d}, J=16 \mathrm{~Hz}, \mathrm{H}-8)$, The ${ }^{13} \mathrm{C}-\mathrm{NMR}$ spectrum of the compound exhibited signals at $\delta 169.80(\mathrm{C}-9), 148.03$ (C-4), 145.76 (C-3), 145.5C7), 126.43 (C-1), 121.57 (C- 6), 115.15 (C-5), 114.11(C-2), 113.77 (C-8) From the above mentioned data, the compound identified as caffeic acid, which confirmed by direct comparison with published data (Kragujevac. (2017).

\section{Compound 2}

It was isolated as white amorphous powder. ESI-MS of the compound showed $[\mathrm{M}-\mathrm{H}]^{+}$peak at $\mathrm{m} / \mathrm{z}$ 353.4, which is compatible with the molecular formula $\mathrm{C}_{16} \mathrm{H}_{18} \mathrm{O}_{9}$.

The ${ }^{1} \mathrm{H}$ NMR spectrum of the compound exhibited characteristic signals for $\delta$ $7.60\left(1 \mathrm{H}, \mathrm{d}, J=16 \mathrm{~Hz}, \mathrm{H}-7^{\prime}\right), 7.07\left(1 \mathrm{H}, \mathrm{d}, J=2.0 \mathrm{~Hz}, \mathrm{H}-2^{\prime}\right), 6.98(1 \mathrm{H}, \mathrm{dd}, J=8.0,2.0$ Hz, H-6'), 6.81(1H, d, $\left.J=8.0 \mathrm{~Hz}, \mathrm{H}-5^{\prime}\right), 6.30\left(1 \mathrm{H}, \mathrm{d}, J=16 \mathrm{~Hz}, \mathrm{H}-8^{\prime}\right), 5.37(1 \mathrm{H}, \mathrm{ddd}, J$ $=6.8,6.8,4.4 \mathrm{~Hz}, \mathrm{H}-5), 4.21(1 \mathrm{H}, \mathrm{ddd}, J=7.2,4.19,4.18 \mathrm{~Hz}, \mathrm{H}-3), 3.77(1 \mathrm{H}, \mathrm{dd}, J=$ 6.8, 3.75 Hz, H-4), $2.28(1 \mathrm{H}, \mathrm{m}, \mathrm{H}-2 \mathrm{ax}), 2.23(1 \mathrm{H}, \mathrm{m}, \mathrm{H}-6 \mathrm{ax}), 2.12(1 \mathrm{H}, \mathrm{dd}, J=13.2$, $4.0 \mathrm{~Hz}, \mathrm{H}-6 \mathrm{eq}), 2.10(1 \mathrm{H}$, dd, $J=13.2,7.6 \mathrm{~Hz}, \mathrm{H}-2 \mathrm{eq})$

The ${ }^{13} \mathrm{C}-\mathrm{NMR}$ spectrum of the compound exhibited signals at $\delta 175.64(\mathrm{C}-7)$, 167.31 (C-9'), 148.16 (C-4'), 145.72 (C-3'), 145.38 (C-7'), 126.41 (C-1'), 121.63 (C- 6'), 115.11 (C-5'), 113.87 (C-2'), 113.84 (C-8'), 74.77 (C-1), 72.10 (C-5), 70.57 (C- 4), 69.92 (C-3), 37.40 (C-2), 36.81 (C-6). From the above mentioned data, the compound identified as chlorogenic acid, which confirmed by direct comparison with published data (Jelena T. et al., 2017)

\section{Compound 3}

The compound was obtained as a yellow amorphous powder. The ESI-MS of the compound showed a peak at $\mathrm{m} / \mathrm{z} 302.0$ for $[\mathrm{M}+\mathrm{H}]{ }^{+}$indicating that the molecular formula is $\mathrm{C}_{15} \mathrm{H}_{10} \mathrm{O}$. The ${ }^{1} \mathrm{H}-\mathrm{NMR}$ spectrum of the compound showed a clear flavonol type pattern of aromatic proton signals; two meta coupled protons each at $\delta 6.19 \mathrm{ppm}$ $(\mathrm{d}, J=2.0, \mathrm{H}-6)$ and $\delta 6.41 \mathrm{ppm}(\mathrm{d}, J=2.0, \mathrm{H}-8)$, doublet of one proton at $\delta 6.90 \mathrm{ppm}(\mathrm{d}$, $\left.J=8.4 \mathrm{~Hz}, \mathrm{H}-5^{\prime}\right)$ and a meta coupled doublet of one proton at $\delta 7.68 \mathrm{ppm}(\mathrm{d}, J=2.0, \mathrm{H}-$ 2 ) and H-6' appear as doublet of doublet at $7.55 \mathrm{ppm}(\mathrm{dd}, J=8.4,2.0, \mathrm{H}-6)$. This data indicated that the compound is a $3,5,7,3,4$-penta oxygenated flavone derivative, which is in a good agreement with Quercetin (Markham, K. R 1982, Mabry, T. J. et al., 1970). The ${ }^{13} \mathrm{C}-\mathrm{NMR}$ spectrum of the compound supporting the structure assignment made above, revealing the presence of 15 carbon signals, including 8 oxygenated at $\delta$ 145.11 (C-2), 160.78 (C-5), 163.97 (C-7), 156.21 (C-9), 146.86 (C-3), 135.78 (C-3), $\delta$ $175.89(\mathrm{C}-4)$ and $\left.147.75\left(\mathrm{C}-4^{-}\right)\right] .7$ non-oxygenated at $[\delta 98.26(\mathrm{C}-6), 93.42(\mathrm{C}-8)$, 103.07 (C-10), $122.04\left(\mathrm{C}-1^{\prime}\right), 115.14\left(\mathrm{C}-2^{\circ}\right), 115.67\left(\mathrm{C}-5^{\prime}\right)$ and $120.05\left(\mathrm{C}-6^{\prime}\right)$ (Harborne, J. B. 1994, Markham, K. R. et al., 1978\& Agrawal, P. K.: 1989). On the basis of the above mentioned data and by comparison with that reported in literature, the compound was identified as Quercetin. 


\section{Compound 4}

This compound was obtained as a yellow powder. The negative mode ESI-MS of compound showed a peak at $\mathrm{m} / \mathrm{z} 609.2$ for $(\mathrm{M}-\mathrm{H})^{-}$, this signal correspond to the molecular formula $\mathrm{C}_{27} \mathrm{H}_{30} \mathrm{O}_{16}$. The ${ }^{1} \mathrm{H}-\mathrm{NMR}$ spectrum of the compound showed two meta-coupled doublets of one proton each at $\delta 6.19 \mathrm{ppm}(\mathrm{d}, J=2.0 \mathrm{~Hz} \mathrm{H}-6)$ and $\delta 6.39$ $\operatorname{ppm}(\mathrm{d}, J=2.0 \mathrm{~Hz} \mathrm{H}-8)$, one ortho-coupled doublet of one proton at $\delta 6.85 \mathrm{ppm}(\mathrm{d}, J=$ $\left.8.8 \mathrm{~Hz}, \mathrm{H}-5^{\prime}\right)$, a douplet of douplet of one proton at $\delta 7.53 \mathrm{ppm}(d d, J=7.2,2 \mathrm{~Hz} \mathrm{H}-6$ ') and a meta-coupled douplet of one proton at $\delta 7.55 \mathrm{ppm}\left(\mathrm{d}, J=2.4 \mathrm{~Hz} \mathrm{H}-2^{2}\right)$. These data indicated that the compound was a 3,5,7,3`4-penta-oxygenated flavonoid derivative, which is in good a greement with quercetin. Its ${ }^{1} \mathrm{H}-\mathrm{NMR}$ spectrum exhibited two anomeric proton signals at $\delta 5.35 \mathrm{ppm}(1 \mathrm{H}, d, J=7.2 \mathrm{~Hz}, \mathrm{H}-1$ " of glucose $)$ and $\delta$ $4.39 \mathrm{ppm}\left(1 \mathrm{H}, d, J=1.6 \mathrm{~Hz}, \mathrm{H}-1^{\prime}\right.$ ' of rhamnose) which were consistent with the configurations $\beta$ for D-glucose and $\alpha$ for L-rhamnose, respectively. In addition, the apppearance of the strong sharp douplet at $\delta 1.002 \mathrm{ppm}(3 \mathrm{H}, d, J=6.4 \mathrm{~Hz}$, secondary$\mathrm{CH}_{3}$ of rhamnose) confirmed the rhamnose unit. The chemical shift value of the anomeric proton of glucose $(\delta 5.35 \mathrm{ppm})$ supported that the glucose attached to aglycone on the other hand, the chemical shift value of the anomeric proton of rhamnose $(\delta 4.39 \mathrm{ppm})$ confirmed that the rhamnose unit must be linked to the glucose moiety (Markham, K. R 1982, Mabry, T. J. et al., 1970). The ${ }^{13} \mathrm{C}-\mathrm{NMR}$ spectrum also supported the structure assignments made above and, in particular, confirmed the presence of one rhamnose moiety followed from the signal of a methyl group $(\delta 17.75)$. The biglycosidic sugar moiety must be attached to the position C-3 of the aglycone, due to the upfield shift $(\delta 133.33)$ of this carbon signal in comparison to that of quercetin $(\mathrm{C}-3, \delta 135.6$; $O$-glycosylation effect). The attachement of the rhamnose to $\mathrm{C}-6$ " of glucose moiety was also deduced by ${ }^{13} \mathrm{C}$-NMR spectrum due to the downfield shift of the glucose C-6" signal from 61.0 to $67.02 \mathrm{ppm}$ (due to rhamnosylation at C-6"), (Harborne, J. B. 1994, Markham, K. R. et al., 1978\& Agrawal, P. K.: 1989). . On the basis of the above mentioned data, this compound was identified as Quercetin-3-O Rutinoside (Rutin). 
<smiles>O=C(O)/C=C/c1ccc(O)c(O)c1</smiles>

Compound 1<smiles>O=c1c(O)c(-c2ccc(O)c(O)c2)oc2cc(O)cc(O)c12</smiles>

Compound 3<smiles>O=C(/C=C/c1ccc(O)c(O)c1)OC1C[C@](O)(C(=O)O)C[C@H](O)[C@H]1O</smiles>

Compound 2

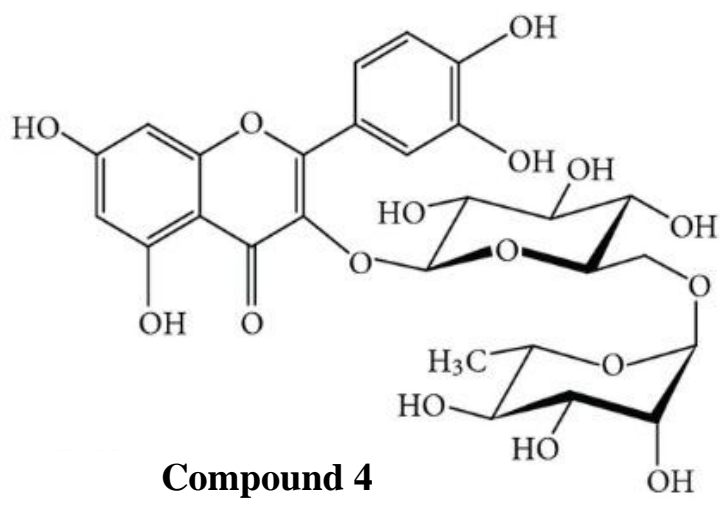

\section{Anti-eczematic activity results:}

A placebo-control trial comparing the ointments were prepared from the ethyl acetate fraction, Nandina domestica with $0.1 \%$ mometasone furoate ointment and placebo of vaseline. Treatment was continued until complete recovery of the induced eczema. The animals were investigated every day and the cured animals were recorded. At the end of the test period the total number of the cured animals was recorded. Results are listed in table below. 
Anti-eczematic activity of $2 \%$ w/w ethyl acetate extract of Nandina domestica against $0.1 \% \mathrm{w} / \mathrm{w}$ mometasone furoate and vaseline (placebo).

\begin{tabular}{cccc} 
Days of & \multicolumn{3}{c}{ No. of cured mice } \\
\cline { 2 - 4 } treatment & $\begin{array}{c}2 \% \text { ethyl acetate of } \\
\text { Nandina domestica }\end{array}$ & $\begin{array}{c}0.1 \% \text { mometasone } \\
\text { furoate (standard) }\end{array}$ & $\begin{array}{c}\text { Placebo } \\
\text { (Vaseline) }\end{array}$ \\
\hline $1^{\text {st }}$ & 0 & 0 & 0 \\
\hline $2^{\text {nd }}$ & 0 & 0 & 0 \\
\hline $3^{\text {rd }}$ & 0 & 0 & 0 \\
\hline $4^{\text {th }}$ & 1 & 2 & 0 \\
\hline $5^{\text {th }}$ & 2 & 1 & 0 \\
\hline $6^{\text {th }}$ & 2 & 1 & 0 \\
\hline $7^{\text {th }}$ & 1 & 2 & 0 \\
\hline $8^{\text {th }}$ & 1 & 0 & 0 \\
\hline 9 th & 0 & 0 & 0 \\
\hline $10^{\text {th }}$ & 0 & 0 & $0 \%$ \\
\hline Total/group & 7 & 6 & 0 \\
\hline N = 8 & $87.5 \%$ & $75 \%$ & 0 \\
\hline$\%$ of cure & & & 0 \\
\hline
\end{tabular}

\section{Conclusion:}

Study of the effectiveness of Nandina domestica leaves ethyl acetate extract in management of the induced eczema revealed that, Nandina domestica leaves ethyl acetate extract was more effective than placebo and $0.1 \%$ mometasone furoate in treatment of induced eczema in mice.

\section{Acknowledgment:}

Thanks are due to Prof. Dr. Ahmed Mansour, Professor of Pharmacology, AlAzhar University, Faculty of Pharmacy, Pharmacology department, Cairo, Egypt for supporting the anti-eczematic activity in laboratory animals. 


\section{References:}

Abdallah M.A.-R., Farag A.M.; A (1994) Colour Atlas of Common Skin Diseases, University Book Center, Cairo, Egypt.

Agrawal, P. K. (1989): “Carbon-13 NMR of Flavonoids” Elsevier Oxford, New York: 96-116.

Cabral P.S., Leite L. and Pinto J. (2003) Handbook of Dermatology \& Venereology: Social Hygiene Handbook ; Department of Dermatology - Hospital Pulido Valente, Lisbon). 2nd Ed.,.

Carvalho J.C.T., Santos L.S. , Viana E.P., Almeida S.S.M.S., Marconato E., Rodrigues M., Ferreira L.R. and de Kamp A.V. (1999) ; Pharmaceutical Biology; 37(4), 281-4.

Congora L., Giner R.M., Manez S., Recio M.C. and Rios J.L. (2002) Phagnalon rupestre as a source of compounds active on contact hypersensitivityPlanta Medica; 68, 561-4.

Dattner A.M. (2003) ; Dermatologic Therapy ;16, 106-13.

Donfack J. Hubert - Amadou Dawe - Ngueguim T. Florence - Kapche D. W. F. Gilbert Feingold S., Huang C., Kristal L., Kalish R. and Clark R.A.F. (1998) Current Problems in Dermatology; 10(2), 41-90.

Fulvio Marzatico - Moundipa F. (2011) Paul In vitro hepatoprotective and antioxidant activities of crude extract and isolated compounds from Ficus gnaphalocarpa Inflammopharmacol 19:35-43.

Graf J. (2002) Skin Therapy Letter ; 5(4), 3-5.

Harborne, J. B (1994) “The Flavonoids, Advances in Research Since" Chapman and Hall, London, New York: 446-71.

Herman S.M. and Vender R.B. (2003); Journal of Cutaneous Medicine and Surgery; 7(6), 467-73.

Hehmann M., Lukacin R., Ekiert H. and Matern U. (2004) ; Eur. J. Biochem.; 271, 932-40.

Jelena T., Svetlana M., (2017) Croat. Chem. Acta, 89(4), 535-541

Khandpur S., Sharma V.K. and Sumanth K. (2004) ; J. Postgrad. Med.; 50(2),131-9.

Kimata M., Inagaki N. and Nagai H. (2000) Effects of luteolin and other flavonoids on IgE-mediated allergic reactions; Planta Medica; 66, 25-9.

Kragujevac J. (2017) Sci. 39 99-108.

Lv YJ, Jia FL, Ruan M, (2008) Zhang BX The hepatoprotective effect of aqueous extracts from Ficus hirta on $\mathrm{N}, \mathrm{N}$-dimethylformamide induced acute liver injury in mice Zhong Yao Cai, September. 
Mabry, T. J., Markham, K. R. and Thomas, M. B. (1970): "The Systematic Identification of Flavonoids" Springer-Verlag, New York, Berlin.

Markham, K. R., Ternai, B., Stanley, R., Geiger, H. and Mabry, T. J. (1978): "Carbon-13 NMR studies of flavonoids-III naturally occurring flavonoid glycosides and their acylated derivatives" Tetrahedron, 34: 1389-97.

Markham, K. R. (1982): “Techniques of Flavonoid Identification" Academic Press Inc., London, 36-49.

Mills S., Bone K., Corrigan D., Duke J.A. and Wright J.V. (2000); Principle and Practice of Phytotherapy: Modern Herbal Medicine; Churchill Livingston, New York, 1st ed,

Mokhber-Dezfuli, N., et al. (2014). "Phytochemistry and pharmacology of berberis species." Pharmacogn Rev 8(15): 8-15.

Saxena N., Bidwari A., Saxena N.K., Ram P. and Bodke R.R. (1988) ; Journal of Tropical Forestry; 4(3), 281-4.

Skripkin Y.K. and Milich M.V.(1994) ; Skin and Venereal Diseases; MIR Publishers; Moscow.

Phelps R.G., Miller M.K. and Singh F. (2003) ; Clinics in Dermatology ; 21, 95-100.

Tchana N. Angele • D. Buonocore • P. Vita Finzi • G. Vidari • Ngadjui T. (1999) Bonaventure World Health Organization ;WHO Monographs On Selected Medicinal Plants; Vol 2 ,World Health Organization, Geneva,1st ed.,

$$
\begin{aligned}
& \text { القاعلية المضادة للأكزيما المستحثة فى الفئران } \\
& \text { 1كاميليا فولي طه، 'ايمان شوقي أنور، 3مروه سامي أبو بكر, مروه خليل رأفت . }
\end{aligned}
$$

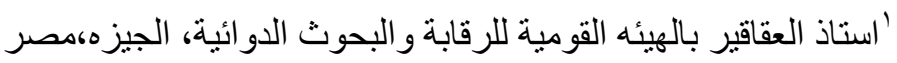

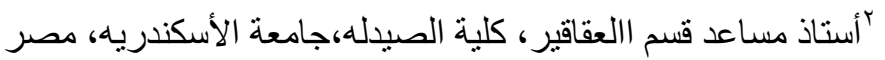

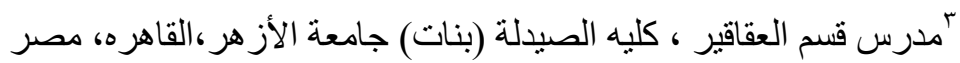

يتجه العالم حديثا للعلاج بالأعشاب لأنه أكثر أمان من الأدويه المصنعه، نبات ناندينا دوماستيكا الذي ينتمي لعائله

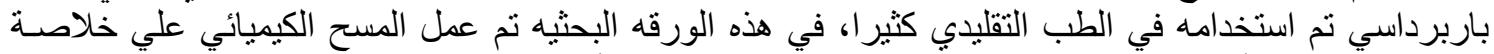

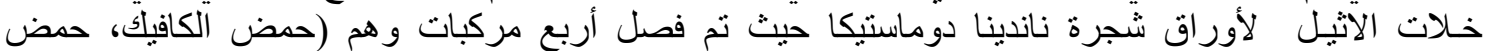
الكلوروجينيك، الكو ارسيتين و الروتين).

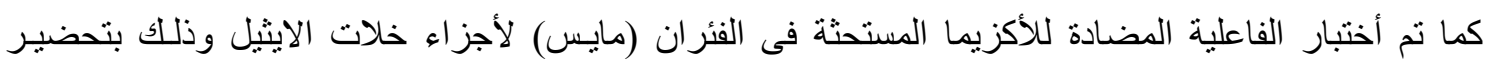

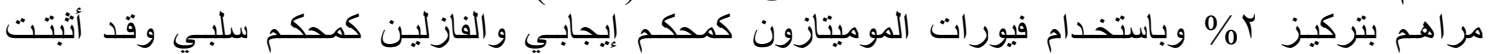

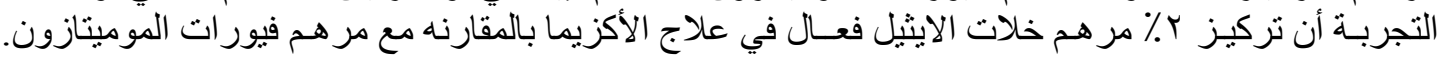

